Z. klin. Chem. u. klin. Biochem.

8. Jg., S. $520-524$, September 1970

\title{
Lipid Screening by Thin Layer Chromatography
}

\author{
By T. Postma and J. A. P. Stroes \\ Sticbting Samenverking Delftse Ziekenbuizen, Delft, The Netherlands
}

(Eingegangen am 22. Mai 1970)

A thin layer chromatographic method for the analysis of lipids in serum is described. Sterol esters, triglycerides, free sterols, free fatty acids, and phospholipids can be separated. After charring by heating with $10 \%$ sulphuric acid and clearing with a clearing solution, the thin layer chromatograms can be scanned with the Analytrol Scanner. This method permits phenotyping of hyperlipoproteinaemia, and a rapid evaluation of the ratio of the five most important lipid components can be made.

Eine dünnschichtchromatographische Methode zur Bestimmung der Serumlipide wird beschrieben. Sterinester, Triglyceride, freies Cholesterin, freie Fettsäuren und Phospholipide können bestimmt werden. Näch Verkohlen durch Erhitzen mit 10proz. Schwefelsäure und Aufhellen mit einer Transparenzbad-Lösung können die Dünnschichtchromatogramme mit dem Analytrol Scanner ausgewertet werden. Die Methode erlaubt, den Phänotyp von Hyperlipoproteinämien festzustellen. Das Verhältnis der fünf bedeutendsten Lipidkomponenten kann in kurzer Zeit bestimmt werden.

In a previous article (1) we described methods for the routine classification of the most common types of primary hyperlipoproteinaemia according to FREDERICKSON and Coworkers (2). These methods included the determination of cholesterol, triglycerides, and total lipids, as well as an electropherographic procedure for the analysis of the lipoproteins on cellulose acetate. Recently, vaN GENT (3) described a method for the separation and microdetermination of lipids by thin layer chromatography followed by densitometry, based on the work of PeIfer (4). With this method it is possible to determine the relative amounts of sterol esters, triglycerides, free sterols, free fatty acids, and total phospholipids in serum.

This article reported the densitometric analysis of lipid extracts from only 6 sera. To explore wider applications, we applied the method to a larger number of sera, evaluated the method statistically, compared the relative amounts of sterol ester, triglycerides, free sterols and total phospholipids with those found by routine methods, and attempted to determine whether it was possible to arrive at a classification of types II, III, and IV according to FREDERICKSON by means of thin layer chromatography.

\section{Methods}

Quantitative analysis of the blood lipids

Total lipids were determined according to DREvon and SCHMrT $(5,1)$.

Free and total cholesterol wete determined according to SPERRY and Webs (6). Sterol esters were calculated from the difference between free and total cholesterol, multiplying by a factor 1.7. For the determination of the triglycerides we used the enzymatic procedure of EgGSTEIN and KreuTz (7) (Boehringer Mannheim GmbH, W. Germany). Phospholipids were determined according to WACHTER (8) $(\mathrm{mg} / 100 \mathrm{~m} /$ lipid-phosphorus $\times 25=\mathrm{mg} / 100 \mathrm{~m} /$ phospholipids). The free fatty acids were not determined quanti- tatively, since they have no relevance for classification according to FrEDERICKSON.

\section{Preparation of the serum for thin layer chromatography}

For the chromatographic separation, the lipid mixture dissolved in chloroform is applied to a thin-layer slide. The serum lipid mixtures were prepared by a zinc precipitation and an extraction with FoLCH solvents according to FrIEDMAN (9).

\section{Reagents}

Acid zinc reagent, prepared by $35: 1000$ dilution of a stock solution containing $100 \mathrm{~g} \mathrm{ZnSO}_{4} \cdot 7 \mathrm{H}_{2} \mathrm{O}$ and $250 \mathrm{mVal} \mathrm{H}_{2} \mathrm{SO}_{4} / l$.

$\mathrm{NaOH}, 0.375 \mathrm{~N}$, adjusted so that $20.0 \mathrm{ml}$ of acid zinc reagent requires $5.0 \pm 0.05 \mathrm{~m} l$ to neutralize to phenolphthalein.

Cbloroform p. a.

Methanol p. a.

Method

To $10 \mathrm{ml}$ zinc reagent in a centrifuge tube fitted with a glass stopper, add $0.5 \mathrm{~m} l$ serum. After mixing on a Vortex mixer, add $0.5 \mathrm{ml}$ of $0.375 \mathrm{~N} \mathrm{NaOH}$.

Stopper the tube, mix thoroughly, and let stand at room temperature for $5 \mathrm{~min}$. Centrifuge at $2500-3000 \mathrm{rpm}$ for $10 \mathrm{~min}$. Decant and discard the supernatant. Drain the tube over filter paper for $5 \mathrm{~min}$. Mix the precipitate thoroughly with $12.5 \mathrm{ml}$ distilled water and centrifuge again. After discarding the supernatant and draining as above, add $5 \mathrm{ml}$ methanol followed by $10 \mathrm{ml}$ chloroform and mix the precipitate vigorously for 1 minute. After centrifugation, decant the clear supernate into another centrifuge tube.

Evaporate the extract to dryness in a $50^{\circ}$ waterbath under a stream of nitrogen. Cool as soon as the last traces of solvent have disappeared, and dissolve the residue in chloroform, using $0.05 \mathrm{ml}$ chloroform per $100 \mathrm{mg} / 100 \mathrm{ml}$ total lipid. The total lipids of the extracted serum have, of course, been determined before the extraction, by the method of Drevon and Schomit (5). Close the centrifuge tube with a glass stopper.

The serum extract is now ready for thin layer chromatography.

\section{Chromatographic Procedure}

For the chromatographic separation of the lipids in the serum extract, a modification of the method of VAN GENT (3) is used. Using a special clearing solution (see under Reagents), it is possible to scan the chromatograms with the Analytrol scanner. 


\section{Materials}

1. Glass slides, $76 \times 26 \mathrm{~mm}$, to which the silica gel is applied.

2. 2 hot-plates, one kept at $100^{\circ}$ and the other at $200^{\circ}$.

3. A small chromatography chamber $(3.5 \times 5.5 \times 10 \mathrm{~cm})$ for the development of the chromatograms. This chamber must be fitted with a close-fitting lid. The best results are obtained with these small chambers and the small thin layer plates if the lid ist completely sealed with tape.

4. A pair of tweezers.

5. A fine capillary, drawn out to a small point, for applying the extract to the silica gel. About $10 \mu l$ extract is to be applied.

6. A spray gun (Shandon).

7. Analytrol Scanner (Beckman Model R. B.).

Reagents

1. Silica gel (Silikagel D. O., Camag).

2. Chloroform p. a.

3. Hexane p. a.

4. Sulphuric acid $10 \%$.

5. Clearing solution for making the slides transparent: a mixture of 2 parts Nitro Rubbol Metal Varnish, Colorless (Sikkens N. V. Holland) and 1 part ethyl acetate.

\section{Method}

Make a suspension of $15 \mathrm{~g}$ silica gel in $90 \mathrm{ml}$ chloroform. With stirring, dip two slides into the suspension, holding them together with the tweezers.

Move the slides gently to and fro and then lift them out of the suspension. Separate the slides and dry them at room temperature for several minutes, after which they are ready for use. Apply about $10 \mu l$ of the serum extract to the thin layer slides by means of a fine capillary. The extract is applied as a series of single spots, so close together that they form a band.

Place the slides in the chromatography chamber, which contains chloroform. As soon as the front has reached the middle of the slides, remove and dry them for about 30 seconds at room temperature in the air. Then place them in a second chromatography chamber containing hexane-chloroform $3: 1$.

When the front approaches the top of the slides, take them out of the chamber and dry them as before. Next, spray the slides with $10 \%$ sulphuric acid, using the spray gun. Heat the slides for 30 to 60 seconds on the hot-plate set at $100^{\circ}$ and then on the second hot-plate at $200^{\circ}$ for 15 minutes. Black bands indicating the charred lipids now appear. Cool the slides. To make the slides transparent, flow $2.5 \mathrm{ml}$ of the clearing solution onto each slide, dry for 5 to $10 \mathrm{~min}$. at room temperature in the air, and apply $1 \mathrm{ml}$ clearing solution. Dry again for 5 to $10 \mathrm{~min}$. and apply $1 \mathrm{~m}$ l clearing solution.

Let the slides dry overnight in the air, after which they will be transparent and can be scanned with the Analytrol Scanner. Moreover, the layer can be taken off the slide, making storage more convenient.

All experiments with the thin layer procedure were carried out in duplicate.

\section{Results}

The chromatographic analysis

Figure 1 gives an example of a thin layer chromatogram.

As shown by vaN GENT (3), the number of densitometric units per microgram of lipid is dependent on the composition of the lipid.

To calculate the composition of a mixture, the densitometric values obtained have to be multiplied by a correction factor specific for each component. In our

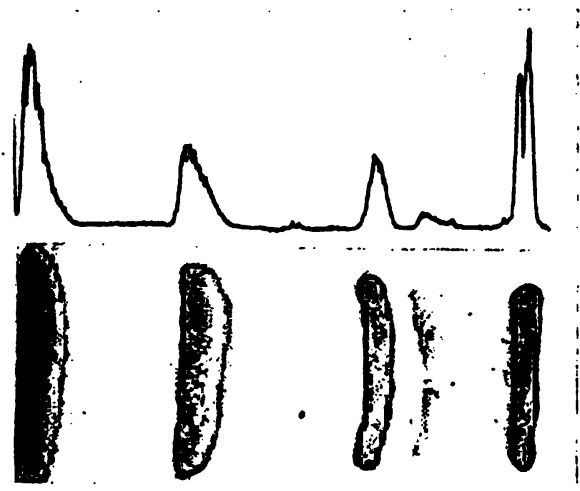

Fig. 1

Thin layer chromatogram of a serum extract. From left to right: bands and peaks of sterol esters, triglycerides, free sterols free fatty acids, and phospholipids

Tab. 1

Correction factors for the calculation of the lipid composition from the densitometric determination. The densitometric values must be multiplied by these factors

\begin{tabular}{ll}
\hline Sterol esters & 1.40 \\
Triglycerides & 1.91 \\
Free sterols & 1.00 \\
Phospholipids & 1.96 \\
Free Fatty Acids & 1.95 \\
\hline
\end{tabular}

Tab. 2

Standard deviation of the chromatographic procedure (40 samples of the same extract from a pooled serum) Relative Peak Area

\begin{tabular}{lrr}
\hline Sterol esters & $37 \%$ & S. D. $2.5 \%$ \\
Triglycerides & $26 \%$ & S. D. $2.2 \%$ \\
Free sterols & $12 \%$ & S. D. $1.6 \%$ \\
Phospholipids & $24 \%$ & S. D. $3.1 \%$ \\
Free Fatty Acids & $1 \%$ & S. D. $0.7 \%$ \\
\hline
\end{tabular}

Tab. 3

Standard'deviation of the extraction procedure (40 samples of different extracts from a pooled serum) Relative Peak Area

$\begin{array}{lrl}\text { Sterol esters } & 40 \% & \text { S. D. } 3.1 \% \\ \text { Triglycerides } & 21 \% & \text { S. D. } 1.7 \% \\ \text { Free sterols } & 8 \% & \text { S. D. } 0.2 \% \\ \text { Phospholipids } & 27 \% & \text { S. D. } 2.3 \% \\ \text { Free Fatty Acids } & 4 \% & \text { S. D. } 0.3 \%\end{array}$

experiments this correctionfactor was determined by comparing the percentages found by chromatographic analysis with the percentages found by the routine method. The correction factors, thus obtained, are given in Table 1.

To evaluate the standard deviation of the chromatographic method, 40 chromatograms of the same extract of a pooled serum were made. The results are shown in Table 2.

In a second experiment we checked the reproducibility of the extraction procedure. Forty extracts were made from a pooled serum and chromatographed. The results are shown in Table 3.

As can be seen from Tables 2 and 3, the reproducibility of the chromatographic and extraction procedure is good. 
Comparison between chromatographic and routine methods

To evaluate the chromatographic procedure further, we compared the relative amounts of sterol esters, triglycerides, free sterols, and phospholipids found by chromatography and the relative amounts found by routine methods (see under Quantitative analysis of the blood lipids).

The results are shown in Table 4. The correlation is significant in all cases $(p<0.001)$.

Tab. 4

Comparison between the relative amounts of sterol esters, triglycerides, free sterol, and phospholipids obtained by chromatography ( $x$ ) and quantitative determinations (y) (90 sera)

\begin{tabular}{llcc}
\hline & \multicolumn{1}{c}{$\mathrm{y}=\mathrm{bx}+\mathrm{a}$} & $\mathrm{r}$ & $\mathrm{p}$ \\
\hline Sterol esters & $\mathrm{y}=0.632 \mathrm{x}+14.6$ & 0.664 & $<0.001$ \\
Triglycerides & $\mathrm{y}=0.923 \mathrm{x}+1.6$ & 0.875 & $<0.001$ \\
Free sterols & $\mathrm{y}=0.468 \mathrm{x}+4.2$ & 0.798 & $<0.001$ \\
Phospholipids & $\mathrm{y}=0.403 \mathrm{x}+16.6$ & 0.476 & $<0.001$ \\
\hline
\end{tabular}

$r=$ correlation coefficient $\quad p=$ level of significance of $r$

The correlation is poorest for the phospholipids; this was to be expected, because the phospholipid band remains at the place where the sample is applied to the chromatogram, and the thin layer is slightly disturbed by the application. This reduces the accuracy of the densitometric evaluation.

\section{Classification of the most common types}

After checking the reproducibility of the chromatographic procedure and comparing this procedure with classical methods, we attempted to arrive at a classification of the most common types according to
Frederickson on the basis of thin layer chromatography. As shown in our previous article (1), this can be done satisfactorily with the cholesterol/triglyceride ratio and the $\beta$ lipoprotein/pre $\beta$ lipoprotein ratio (electrophoretic procedure). Table 5 shows the averages and ranges of the lipid percentages of a number of sera, obtained by normal quantitative methods. Table 6 shows the results with thin layer chromatography.

As can be seen, there is a good agreement between the values in Tables 5 and 6 . The cholesterol/triglyceride ratio, total cholesterol estimated as free sterols + sterol esters $\times 0.59$, is especially suitable for phenotyping hyperlipoproteinaemia. Table 7 gives the values for

Tab. 7

Phenotyping hyperlipoproteinaemia

Comparison of thin layer chromatography with routine methods

\begin{tabular}{lccc}
\hline & Type II & Type III & Type IV \\
\hline $\begin{array}{l}\text { Cholesterol/triglyceride ratio } \\
\text { (PosTMA and STROÉ (1)) }\end{array}$ & $>1.5$ & $0.7-1.5$ & $0.3-0.7$ \\
$\begin{array}{c}\text { Cholesterol/triglyceride ratio } \\
(\text { see Table 5) }\end{array}$ & $>1.6$ & $0.8-1.7$ & $0.3-0.7$ \\
$\begin{array}{c}\text { Cholesterol/triglyceride ratio } \\
\text { (see Table 6) }\end{array}$ & $>1.5$ & $0.7-1.6$ & $0.4-0.6$ \\
\hline $\begin{array}{c}\beta \text { lipoprotein/pre } \beta \text { lipoprotein ratio } \\
\text { (PoSTMA and STROES (1)) }\end{array}$ & $>2$ & $0.7-2.0$ & $<0.7$ \\
\hline
\end{tabular}

the three different ways of phenotyping hyperlipoproteinaemia : the $\beta$ lipoprotein/pre $\beta$ liproprotein ratio, the cholesterol/triglyceride ratio, and the cholesterol/triglyceride ratio obtained by thin layer chromatography. There is a very good agreement indeed between the results of routine methods and thin layer chromatography.

Tab. 5

Lipid analysis by routine quantitative methods Percentage of total lipids

(Average and range)

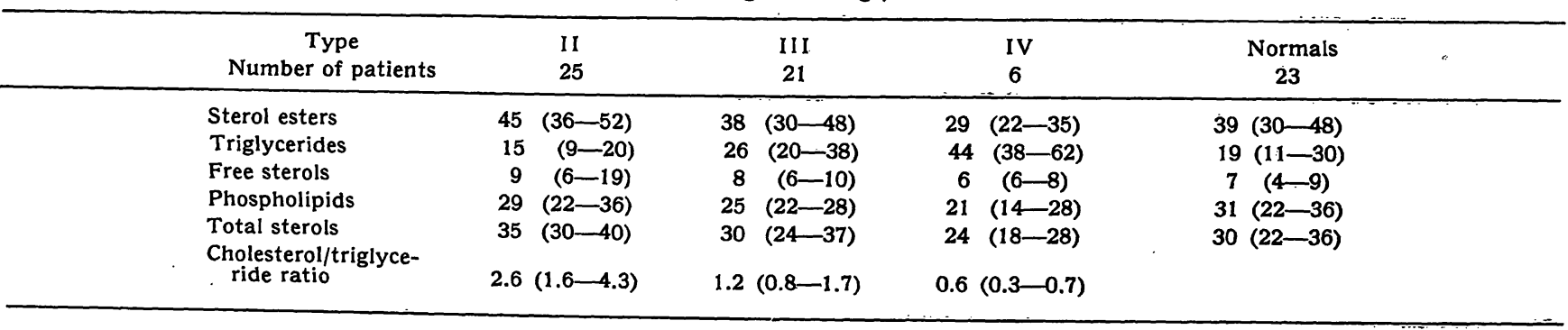

Tab. 6

Lipid analysis by thin layer chromatography

Relative peak area (corrected by multiplication with charring factor) (Average and range)

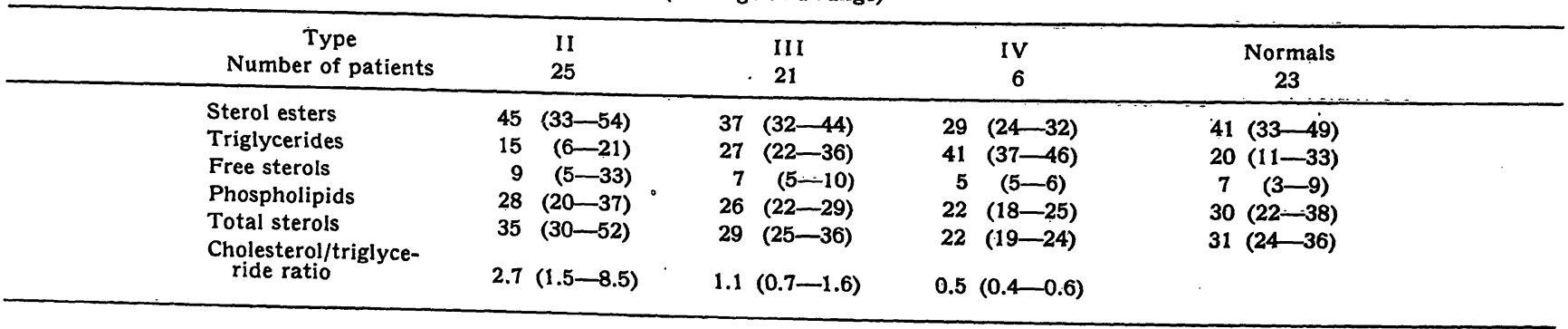


Tab. 8

Some values from sera analyses for hyperlipoproteinaemia by routine quantitative methods (QM) and by thin layer chromatography (TLC)

\begin{tabular}{|c|c|c|c|c|c|c|c|c|c|c|c|c|c|c|c|c|}
\hline \multirow[b]{2}{*}{$\begin{array}{l}\text { Total Lipids } \\
\mathrm{mg} / 100 \mathrm{ml}\end{array}$} & \multicolumn{3}{|c|}{ Sterol esters } & \multicolumn{3}{|c|}{ Triglycerides } & \multicolumn{3}{|c|}{ Free sterols } & \multicolumn{3}{|c|}{ Phospholipids } & \multirow{2}{*}{\multicolumn{2}{|c|}{$\begin{array}{l}\text { Total Chol- } \\
\text { esterol*) } \\
\text { \% } \\
\text { \% }\end{array}$}} & \multirow[b]{2}{*}{ 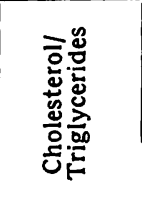 } & \multirow{3}{*}{ 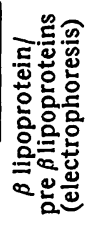 } \\
\hline & $\begin{array}{l}\tilde{E} \\
\frac{8}{\bar{E}} \\
\text { E }\end{array}$ & 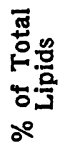 & $\%$ & $\begin{array}{l}\text { E } \\
\stackrel{8}{C} \\
\frac{\text { ED }}{E}\end{array}$ & 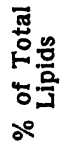 & $\%$ & 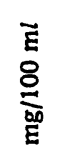 & 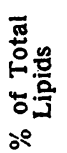 & $\%$ & $\frac{\vec{E}}{\stackrel{8}{E}}$ & 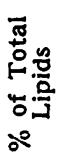 & $\%$ & & & & \\
\hline $\mathbf{Q M}$ & $\mathbf{Q M}$ & $\mathbf{Q M}$ & TLC & $\mathbf{Q M}$ & QM & TLC & QM & QM & TLC & $\mathbf{Q M}$ & $Q M$ & TLC & $\mathbf{Q M}$ & TLC & QM TLC & \\
\hline
\end{tabular}

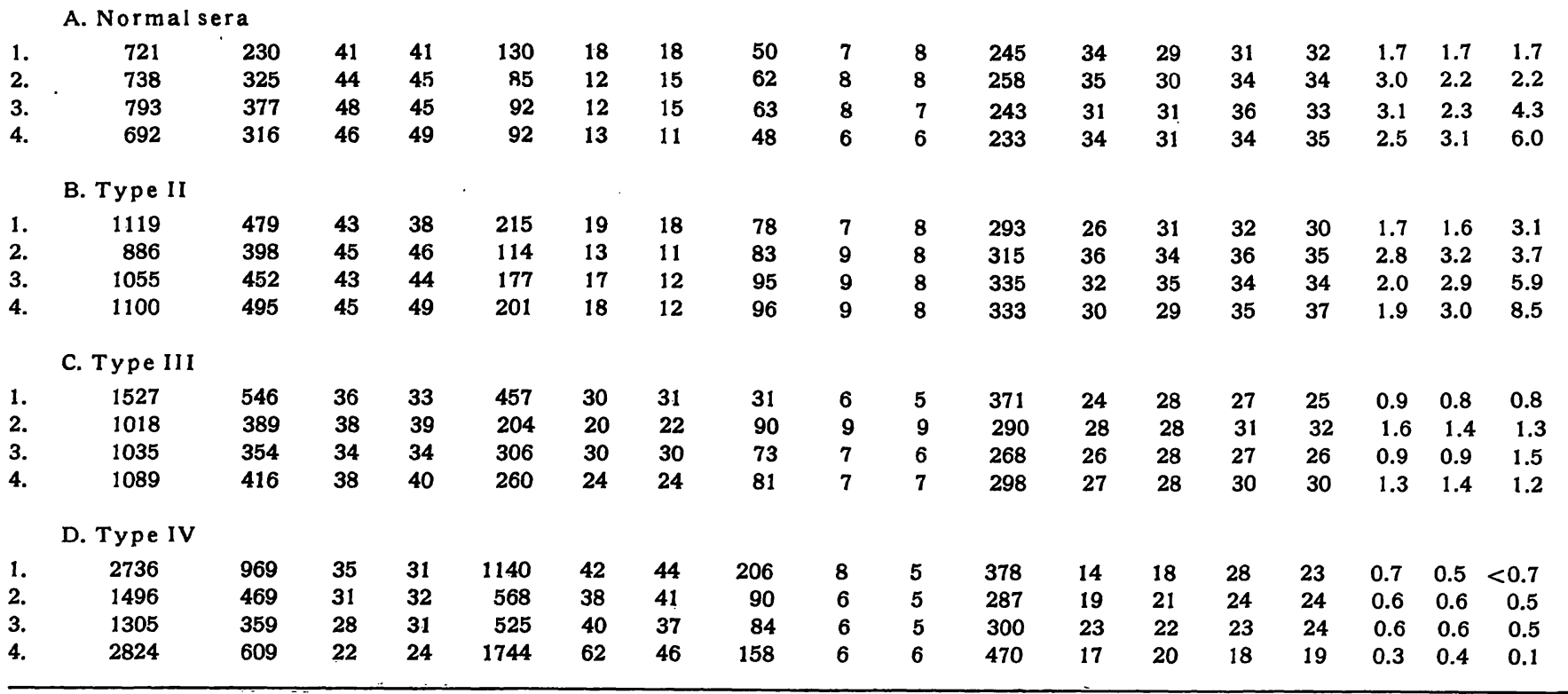

*) Cholesterol from sterol esters and frèe sterols, estimated as free sterols + sterol esters $\times 0.59$.

N. B. The percentages indicated for TLC are corrected percentages multiplied by the correction factor.

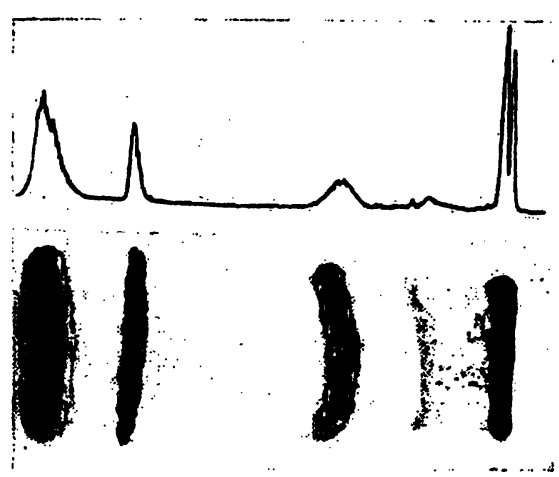

Fig. 2

Thin layer chromatogram of a type 11 hyperlipoproteinaemia

\begin{tabular}{|c|c|c|c|c|}
\hline \multirow{2}{*}{ Lipid } & \multicolumn{3}{|c|}{$\begin{array}{c}\text { Values found by } \\
\text { quantitative determination }\end{array}$} & \multirow{2}{*}{$\begin{array}{c}\text { thin layer } \\
\text { chromatography } \\
\% \text { of total } \\
\text { lipids }\end{array}$} \\
\hline & $\mathrm{mg} / 100 \mathrm{ml}$ & & $\begin{array}{l}\% \text { of total } \\
\text { lipids }\end{array}$ & \\
\hline Total & 1170 & & 100 & 100 \\
\hline Sterol esters & 470 & & 40 & 42 \\
\hline Triglycerides & 214 & & 18 & 21 \\
\hline Free sterols & 74 & & 6 & 7 \\
\hline Phospholipids & 318 & & 27 & 28 \\
\hline $\begin{array}{l}\text { Cholesterol/Tri- } \\
\text { glyceride ratio }\end{array}$ & & 1.6 & & 1.5 \\
\hline $\begin{array}{l}\beta \text { lipoprotein/pre } \\
\beta \text { lipoprotein } \\
\text { :atio (Lipopro- } \\
\text { tein electropho- } \\
\text { resis) }\end{array}$ & & - & & 2.0 \\
\hline
\end{tabular}

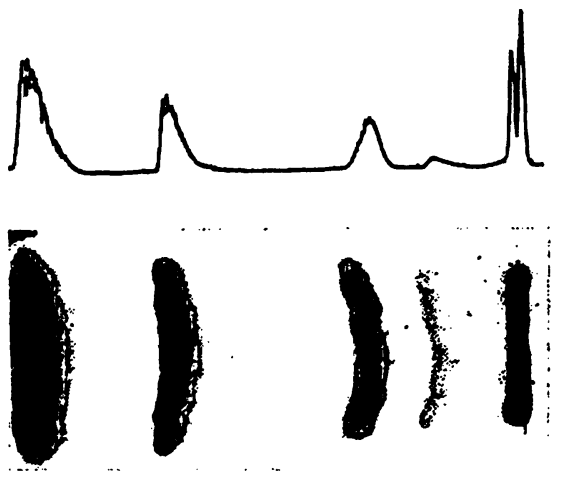

Fig. 3

Thin layer chromatogram of a type III hyperlipoproteinaemia

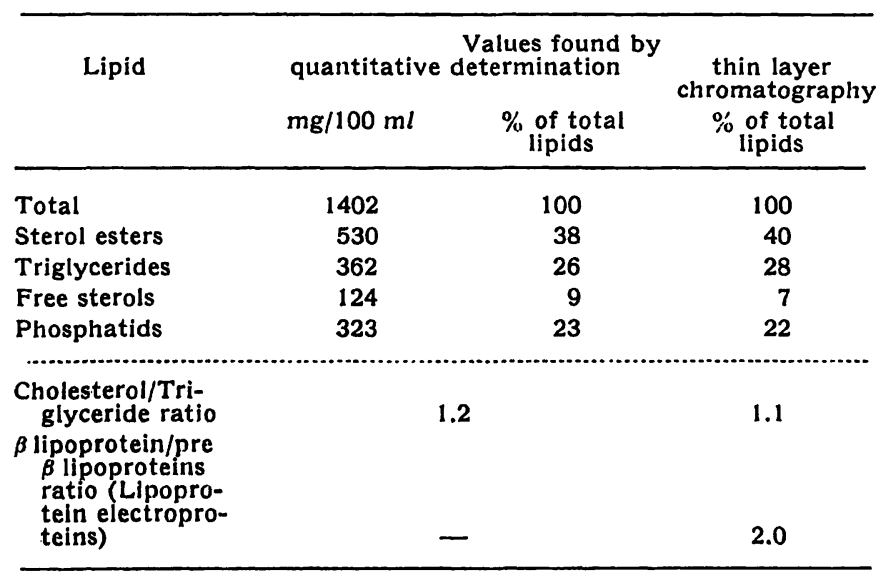


Some examples of chromatograms and values Since the results demonstrate that thin layer chromatography can be used for phenotyping hyperlipoproteinaemia, some examples will be useful. Figures 2,3 , and 4 give examples of types II, III, and IV of hyperlipoproteinaemia, respectively. Table 8 gives some values found in analyses of sera for hyperlipoproteinaemia, with comparison of the results of routine methods and thin layer chromatography. As can be seen from this Table, phenotyping can be done satisfactorily with thin layer chromatography using the criteria given in Table 8.

\section{Conclusions}

Thin layer chromatography offers a good method for phenotyping hyperlipoproteinaemia, in addition to the routine methods (determination of cholesterol and triglycerides and calculation of the cholesterol/triglyceride ratio) and lipid electrophoresis ( $\beta$ lipoprotein/ pre $\beta$ lipoprotein ratio).

When a rapid evaluation must be made of the ration of the five most important lipid components in serum, i. e. sterol iesters, triglycerides, free sterols, free fatty acids and phospholipids, a thin layer chromatogram can give valuable information (Table 4).

We should like to thank Miss J. van Cappellen for her very valuable technical assistance.
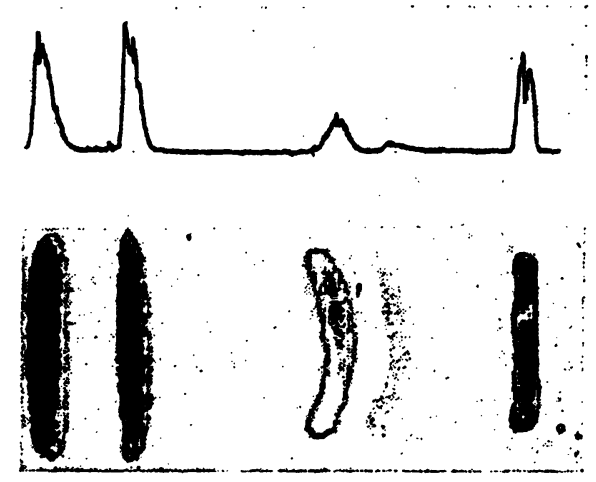

Fig. 4

Thin layer chromatogram of a type IV hyperlipoproteinaemia

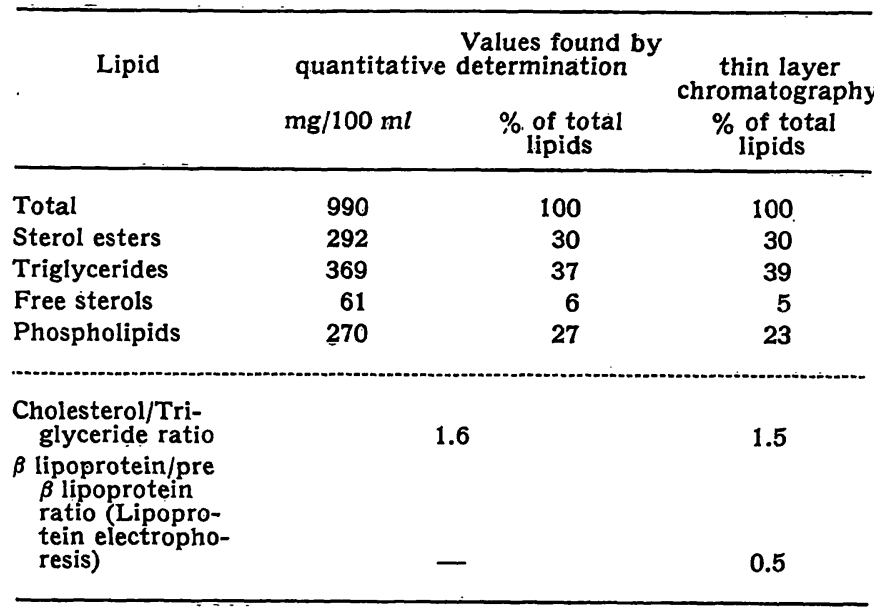

\section{References}

1. Postma, T. and J. A. P. Stroes, Clin. Chim. Acta, Amsterdam 22, 569 (1968). - 2. Frederickson, D. S., R. S. LeVY and R. S. LeEs, N. England J. Med. 276, 34, 94, 148, 215, 273 (1967). 3. VAN GeNt, C. M., Z. analyt. Chem. 236, 344 (1968). - 4. Peifer, J. J., Alikrochim. Acta 3, 529 (1962/1963). - 5. Drevon, B. and J. M. Schmir, Bull. Trav. Soc. Pharmac. Lyon 8, 173
(1964). - 6. SPERRY, W. M. and M. WeBB, J. biol. Chemistry 187, 97 (1950). - 7. Eggstein, M. and F. H. Kreutz, Klin. Wschr. 44, 262 (1966). - 8. WACHTER, H., Arztl. Lab. 11, 11 (1965). - 9. Fruedman, H. S., Clin. Chim. Acta, Amsterdam 19, 291 (1968).
Dr. T. Postma

Stichting Samenwerking Delftse Ziekenhuizen Reynier de Graefweg 7

Delft/Holland 

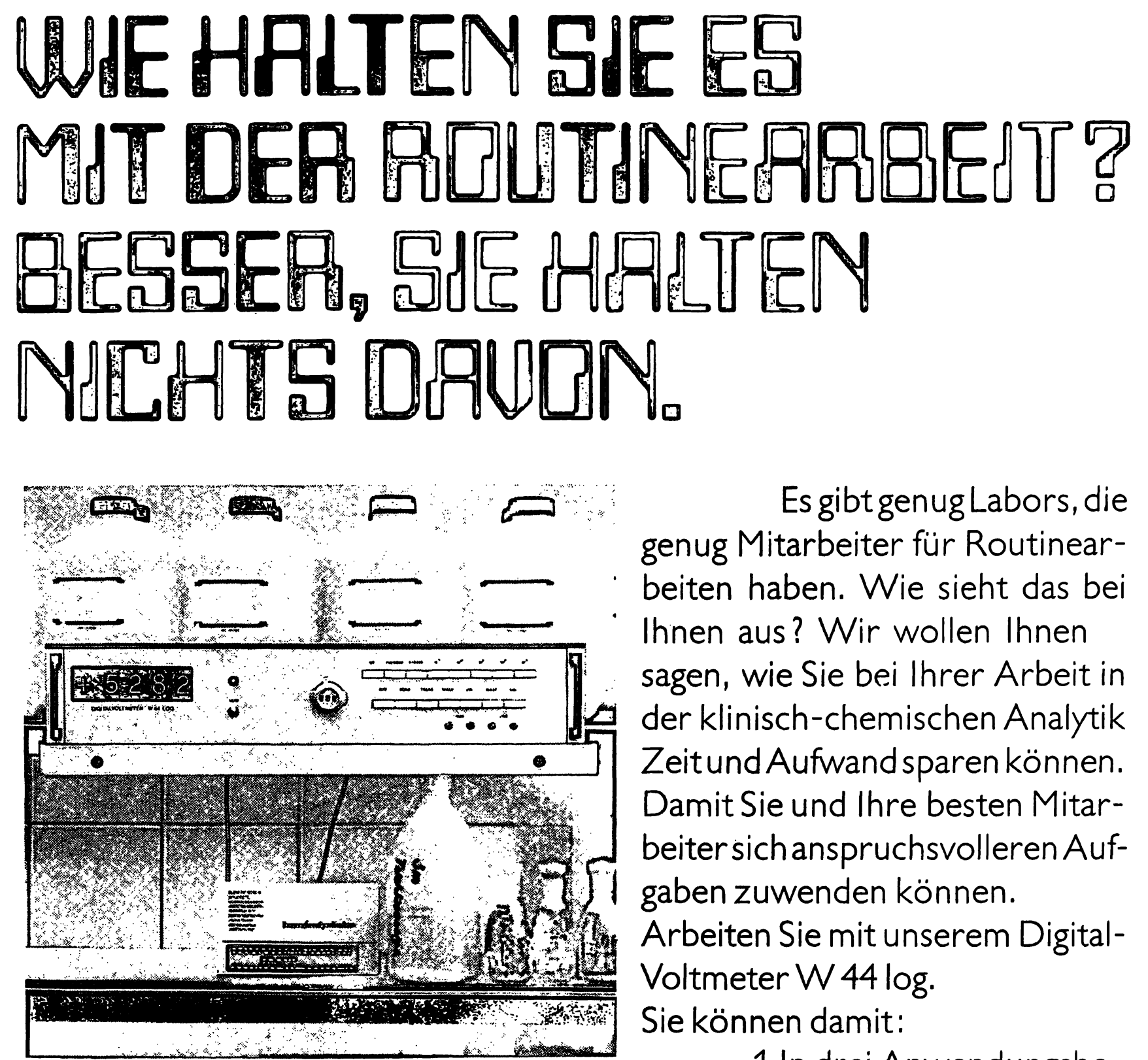

Es gibt genug Labors, die genug Mitarbeiter für Routinearbeiten haben. Wie sieht das bei Ihnen aus? Wir wollen Ihnen sagen, wie Sie bei Ihrer Arbeit in der klinisch-chemischen Analytik Zeitund Aufwand sparen können. Damit Sie und Ihre besten Mitarbeiter sich anspruchsvolleren Aufgaben zuwenden können.

Arbeiten Sie mit unserem DigitalVoltmeter W 44 log.

Sie können damit:

1. In drei Anwendungsbereichen messen. Die Werte von Transmission, Extinktion, Konzentration.

2. Fehler vermeiden. Beim Ablesen, beim Rechnen, beim Schreiben.

3. Und Ihre Arbeit vereinfachen. Durch automatisches Auswerten von Massenanalysen.

Genug Eigenschaften, die Ihnen nicht egal sein sollten.

Informieren Sie sich. Schreiben Siean: Hartmann \& Braun Digital GmbH 1 Berlin $12 \cdot$ Bismarckstraße $107 \cdot$ Telefon (0311) $31131 \cdot$ Telex 1-83783 


\title{
Buddecke \\ Grundriß der Biochemie"
}

\section{für Studierende der Medizin, Zahnmedizin und Naturwissenschaften}

\author{
Von Prof. Dr. Ecrhart Buddecke
}

Mit mehr als 400 Formeln, Tabellen und Diagrammen

XXXII, 499 Seiten. 1970. Plastik flexibel DM 27,50

\begin{abstract}
Die progressive Zunahme des biochemischen Fachwissens erfordert eine überschaubare und zusammenfassende Darstellung der Biochemie als Hilfsmittel für den Unterricht. Der Grundriß der Biochemie von E. Buddecke gliedert den Wissensstoff in die Kapitel „Stoffe und Stoffwechsel“, „Stoffwechselregulation“ und „Funktionelle Biochemie der Organe und Gewebe“ mit dem Ziel, durch knappe Darstellung gesicherter Fakten und gezielte Stoffauswahl dem Leser einerseits eine rasche Information zu bieten, andererseits jedoch auf die vielfältigen Beziehungen und Anwendungsmöglichkeiten der Biochemie zur klinischen Chemie und Molekularpathologie hinzuweisen, um damit dem Studierenden der Medizin und Zahnmedizin sowie der anderen Gebiete der Naturwissenschaften das Verständnis klinischen Fachwissens zu erleichtern.
\end{abstract}

\section{Inhaltsübersicht}

Stoffe und Stoffwechsel

Chemische Zusammensetzung und Stoffwechsel der Zelle - Der Stoffwechsel als chemische Reaktionsfolge Enzyme - Coenzyme - Aminosäuren - Nucleinsäuren Proteine - Glucose und Kohlenhydrate - Lipide - Citratzyklus und biologische Oxydation - Porphyrine - Wasserhaushalt - Mineralhaushalt

Stoffwechselregulation

Selbstregulation durch Rückkopplung - Regulation durch Metabolitkonzentrationen - Enzymkonkurrenz Hormone
Einführung - Glanduläre Hormone - Gewebshormone

Vitamine

Definition und Klassifizierung - Vitamine mit Coenzymfunktion - Vitamine ohne Coenzymfunktion - Vitaminähnliche Wirkstoffe

Funktionelle Biochemie der Organe und Gewebe

Biochemie der Zelle Blut - Leber - Verdauung und Resorption - Niere und Urin - Muskel - Nervengewebe Binde- und Stützgewebe - Wachstum und Abwehr

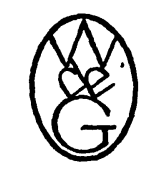

